\title{
Immigration and innovation: Chinese graduate students in U.S. universities*
}

\author{
Patrick Gaulé† \& Mario Piacentini ${ }^{\ddagger}$
}

November 6, 2011

\begin{abstract}
Immigration is rapidly changing the composition of the $R \& D$ workforce in the United States, with important implications for both management and public policy. We study here the Chinese chemists and chemical engineers who migrate to the United States for their graduate studies. We analyze productivity at the individual researcher level, thus bypassing the identification issues that earlier studies had to confront when analyzing the relationship between immigration and innovation at the university or firm level. Using new data and measurement techniques, we find robust evidence that Chinese students make disproportionate contributions to the scientific output of their advisors and departments. We attribute this result to a selection effect as it is relatively more difficult for Chinese students to gain admission into U.S. PhD programs. Our results strengthen the case for liberal student migration policies.
\end{abstract}

- Job market paper -

- A shorter version of this paper has been

resubmitted to the Review of Economics and Statistics -

${ }^{*}$ We thank Ajay Agrawal, Pierre Azoulay, Dominique Foray, Jennifer Hunt, Bill Kerr, Josh Lerner, Jacques Mairesse, Fiona Murray, Maurice Schiff, Paula Stephan, Scott Stern, Yanbo Wang and seminar participants at the NBER Summer Institute, NBER productivity lunch, Brookings Institution and American Economic Association annual meeting for insightful comments, discussions and advice. Maria Eugenia Sagon provided excellent research assistance. Patrick Gaule acknowledges the financial support of the National Bureau of Economic Research through the Innovation Policy and the Economy fellowship. This research project started when both authors were graduate students at the University of Geneva, Switzerland.

${ }^{\dagger}$ Harvard University, patrickgaule@gmail.com

$\ddagger$ OECD, mar.piacentini@gmail.com 


\section{Introduction}

"The first step in winning the future is encouraging American innovation. (...) We're the home to the world's best colleges and universities, where more students come to study than any place on Earth. (...) Today, there are hundreds of thousands of students excelling in our schools who are not American citizens."

(Barack Obama, 2011 State of the Union address)

Immigration is rapidly changing the composition of the $R \& D$ workforce in the United

States. Immigrants represented $37 \%$ of the U.S. Science \& Engineering workforce with doctorate degrees in 2000 compared to 24\% in 1990 (NSF 2007a). The majority of immigrant scientists and engineers in the U.S. came as students (NSF 2007b). In 2009, 55\% of PhD degrees in engineering granted by U.S. universities were to temporary visa holders (NSF 2011), with China the largest source country. In fact, recent PhD graduates from U.S. universities are more likely to have done their undergraduate studies at Tsinghua University or Peking University than at the University of California, Berkeley, or any other institution (Mervis 2008).

The internationalization of the U.S. R\&D workforce has potentially profound implications for firms and for public policy. On the policy side, the key debate is whether immigration policy for foreign students should be liberal, which ultimately depends on whether the U.S. benefits from the influx of foreign scientists and engineers. Migrants may accelerate the rate of U.S. innovation and strengthen U.S. comparative advantage in graduate-intensive sectors of production (Freeman 2009). However, migration of foreign graduate students may crowd out native students (Borjas 2004) or decrease incentives for natives to engage in scientific careers (Borjas 2006). The latter concerns become more salient if a substantial fraction of high-skilled migrants return to their home country after completing their education.

On the management side, one might wonder to what extent U.S. firms should rely on foreign scientists and engineers for the staffing of their R\&D labs. Firms may gain access to engineering and scientific talent not otherwise available by hiring foreign scientists and 
engineers. However, having a more culturally diverse R\&D workforce could potentially have a detrimental effect on performance due to communication or other problems. If the market for scientists and engineers was frictionless, any such consideration would be fully reflected in the wages of foreign scientists and engineers. Opportunities for arbitrage may exist, however, in the presence of frictions in the market for scientists and engineers. The only paper we are aware of in the management literature that speaks to these issues is Mithas \& Lucas (2010) who show that foreign I.T. workers command a wage premium.

This paper contributes to the growing literature on immigration and innovation. Previous studies have typically analyzed the relationship between the innovative performance of cities (Kerr \& Lincoln 2010), states (Hunt \& Gauthier-Loiselle 2010), firms (Kerr \& Lincoln 2010; Passerman 2011) or universities (Stuen, Mobarak \& Maskus 2011; Chellaraj, Maskus \& Mattoo 2008; Gurmu, Black \& Stephan 2010) and the share of migrants in these entities. The problem with this approach is that the non-random assignment of migrants to cities, states, firms or universities requires the development of sophisticated identification strategies. Here, we directly compare the performance of Chinese students with other students in a given university or given lab. Our approach complements the earlier literature and strengthens its findings that migrant scientists and engineers increase the rate of U.S. innovation.

To enable an analysis at the level of the individual student, we collected and merged data from multiple unconventional sources. Dissertation abstracts were used to build lists of students. ${ }^{1}$ We identified Chinese students through an ethnic name matching algorithm as in Kerr (2008a; 2008b). Information on advisors was retrieved from the faculty listings of the American Chemical Society Directory of Graduate Research. Finally, we matched both the students and their advisors to their publications. Our final dataset covers more than 20,000 PhD students graduating from U.S. universities in chemistry, biochemistry and chemical engineering. These fields account for almost a fourth of $\mathrm{PhD}$ degrees in science and engineering granted in the U.S. in 2006 (NSF 2009).

Regressing different measures of productivity on an indicator variable for Chinese student, we find that Chinese students significantly outperform other students. The magnitude of the

\footnotetext{
${ }^{1}$ The use of dissertation abstracts was inspired by the work of Kahn \& MacGarvie (2011; forthcoming).
} 
differential (between $+24 \%$ and $+62 \%$ ) is sensitive to the choice of productivity measure but robust to the inclusion of either school fixed effects or advisor fixed effects. Next, we compare the Chinese students to three other interesting groups of students: the Indian students, the Korean students, and the awardees of the NSF doctoral fellowship program- America's best and brightest in Science and Engineering. Conditional on acceptance into the same program or working with the same advisor, Chinese students perform about as well as the NSF fellows. We also find that the Chinese students outperform both the Indian students and the Korean students. Thus, our results point to the exceptionalism of China with respect to other source countries.

We also run a set of regressions where the unit of analysis is the advisor. We regress the productivity of the advisor as dependent variable on the number of Chinese students and the number of other students graduating that year, the subsequent year and preceding year. Chinese students seem to have a larger effect on the productivity of their advisor than non-Chinese students, which is entirely consistent with the results obtained at the individual student level.

Our preferred explanation for the productivity differential between the Chinese students and other students is a selection effect. Evidence from Attieh and Attieh (1997) suggests that top U.S. universities give substantial preference to U.S. citizens in their admissions decisions. This could reflect a preference for natives but it may also be the consequence of greater uncertainty regarding applicants from other countries. In either case, the bar for admissions is effectively higher for foreign students. The fact that Chinese migrants overwhelmingly come from a small number of elite Chinese universities provides strong support for the importance of these selection processes.

The rest of the paper is organized as follows. We first provide background information on the migration of Chinese students, on the National Science Graduate Fellowships, and on graduate study and knowledge production in chemistry. We then describe our data and present the results. Finally, we discuss potential explanations for the productivity differential between Chinese and other students and conclude. 


\section{Background}

\subsection{Migration of Chinese students}

The U.S. Immigration and Nationality Act of 1952 formalized the status of foreign students in U.S. institutions by creating non-immigrant visa categories permitting temporary residence for study purposes (Bound et al. 2009). The F1 visa grants access to the US to students who are admitted by a recognized academic institution and can prove sufficient financial support. The number of student visas issued by the State Department climbed sharply from 65,000 in 1971 to 315,000 visas in 2000 (U.S. Department of State, Annual Report of the Visa Office, various years).

Until 1978, Chinese migration policy only allowed migration into socialist countries. The relaxation of this policy gave start to a period of steadily rising Chinese migration to the US. In 2002, there were more than 700,000 temporary immigrants to the U.S. from China, about one-tenth of whom were students (USCIS data reported in Poston \& Luo (2007)). Around 325,000 scientists and engineers based in the US in 2003 were born in China, Hong-Kong or Macau (NSF 2007b), of whom around three-fourth had obtained at least one university degree in the US (ibid.).

Since the end of the Cultural Revolution in 1977, China has made considerable investments in its higher education system, both in absolute terms and relative to other countries at similar levels of development. ${ }^{2}$ From 1978 to 2006, the number of institutions of higher education more than tripled $(\mathrm{Li}, 2009)$ and enrollments increased even faster, growing at approximately 30\% a year since 1999 ( $\mathrm{Li}$ et al. 2008). In the 90's, Chinese universities graduated slightly less Bachelors in Science and Engineering than U.S. universities but the number of Bachelors in S/E graduating from Chinese universities rose sharply in the 00s.

Until recently, Chinese universities offered limited possibilities for graduate education. ${ }^{3}$

\footnotetext{
${ }^{2}$ Resource inputs have also been concentrated on a small number of elite institutions and in Science and Engineering departments in particular.

${ }^{3}$ Only slightly more than 1000 doctoral degrees in S/E were awarded in China in 1989 (NSF 2007a). The number of doctoral degrees in S/E awarded by Chinese universities reached 12,000 in 2003 (ibid), which was still only about one third of the the number of doctoral degrees in S/E awarded by US universities in the
} 
Conversely, the leadership position of US universities as providers of high-quality doctoral education is undisputed. Chinese scientists and engineers report educational opportunities as the most important reason for coming to the United States (NSF 2007b).

\subsection{The NSF graduate research fellowship program}

Although we are not interested in the National Science Foundation (NSF) graduate research fellowship (GRF) program per se, we provide a brief of description as the NSF graduate fellows are a useful reference group for assessing the performance of Chinese students. The NSF graduate research fellowship is a highly prestigious award for Science and Engineering students. Freeman et al. (2005) refer to the program as 'Supporting the "Best and Brightest" in Science and Engineering'. Applicants to GRF program have to be either US citizen or permanent residents to be eligible. Around 1,000 fellowships are awarded each year, which amounts to two fellowships per thousand Science and Engineering Bachelors. Applications are evaluated by panels based upon recommendation letters, graduate point average (GPA) obtained in undergraduate studies and quantitative and verbal graduate research examination (GRE) scores. The program provides financial support for three years of graduate study. While the dollar value of the stipend was relatively low in the 90's (at USD 15,000), the prestige of the award is considerable and could easily be leveraged to obtain the best possible financial support from host institutions, as universities actively woo NSF graduate fellows (WestEd 2002).

\subsection{Graduate study and knowledge production in chemistry}

As in much of the physical and life sciences, knowledge production in chemistry is organized in laboratories. Typically, graduate students focus on conducting experiments while the faculty member focuses on conceptual-theoretical activities, including raising grant funding, formulating research questions, designing research projects and interpreting experimental results (Laudel 2001). In the words of the Economist (2007) the graduate student is 'the same year. 
workhorse of the modern laboratory'. Correspondingly, faculty and students work in much closer collaboration than in the social sciences. Authorship practices reflect the division of labor within the lab. The median number of authors per paper is five with the first authorship conferred to the junior scholar who did most of the experiments. The name of the advisor normally appears at the end of the authorship list and more minor contributions to the paper are recognized through authorship slots in the middle. Graduate students are not expected to publish independently of their faculty advisors.

The median enrollment to graduation time is six years for chemistry PhD students (NSF 2006). In the first year of PhD graduate programs, students choose an advisor in whose lab they will conduct research, in principle for the rest of their $\mathrm{PhD}$. They are mainly supported by research assistantships (42.2\%) and teaching assistantships (41.8\%) while around $8 \%$ have fellowships (NSF 2007c). About half of graduating PhD students pursue careers in industry, either in the classical chemical industry or, increasingly, in the pharmaceutical industry. About $30 \%$ of chemistry $\mathrm{PhD}$ graduates pursue careers in the academia.

\section{Data}

We identify PhD students using Proquest Dissertations and Abstracts. This bibliographic database lists abstracts of completed $\mathrm{PhD}$ theses with the name of the student, the university and year of graduation as well as the field and the name of the advisor. It also includes links to the full-text of the theses, which is useful because theses from certain universities include additional bibliographical information on students (MacGarvie 2007).

Proquest data provides a good coverage of $\mathrm{PhD}$ graduates for U.S. universities and recent years. However, we do not directly observe country of birth or of undergraduate education. To address this limitation, we use a technique similar to that pioneered by Kerr (2008a, 2008b) in his study of ethnic patent inventors. This technique relies on the fact that names

implicitly contain information about the origin of individuals and ethnicity can be reasonably well inferred by matching names to lists of ethnic names. Using the same approach, we constructed lists of Chinese last and first names and used them to code students as Chinese. 
To verify the quality of the results obtained with of our ethnic name matching algorithm, we manually coded hundreds of CVs for universities that require students to report biographic information in theses. We find that $88 \%$ of students coded as Chinese had received their undergraduate degrees in China (and a further 5\% in Taiwan). Conversely, our algorithm identified $96 \%$ of students that did their undergraduate studies in China as Chinese (see table 1).

[insert table 1 about here]

We construct scientific output measures by matching our list of students to publication data from Scopus, a bibliographic database from Elsevier. The matching is by no means trivial and its validity is essential to the credibility of our exercise. To minimize errors in the matching process, we exploit the fact that papers authored by chemistry students are almost invariably written with their advisor as coauthor, as discussed earlier. We also use affiliation data for individual authors. ${ }^{4}$ A publication is matched to a student if nine criteria are successfully met: an author of the publication needs to have the (1) last name of the student (2) first initial of the student (3) correct departmental affiliation of the student (4) correct university affiliation of the student; and one of the coauthors of the paper has to have (5) the last name of the advisor (6) the first initial of the advisor (7) the correct departmental affiliation of the advisor and (8) the correct university affiliation of the advisor. Finally, the paper has to be published (9) no earlier than 3 years prior to the graduation of the student and no later than the year of graduation.

Scientific output can be measured by counting the number of publications, or adjusting for the journal impact factor (JIF) (a reasonable proxy for quality of the journal) or by counting the number of cites received by these publications. Moreover, as discussed earlier, first-authorship in chemistry has a special meaning and is typically used to recognize the junior scholar who made the main contribution to the paper. Thus, it is interesting to distinguish between first-authored publications and all publications. Although our preferred

\footnotetext{
${ }^{4}$ Scopus includes affiliation data for individual authors which is not the case for the concurrent bibliographic database ISI Web of Scicne.
} 
measure of productivity is counts of first-authored articles weighted by journal impact factor, we use the other productivity measures as well.

Proquest includes names of $\mathrm{PhD}$ advisors but no other information on them. To enrich our data set, we match advisors from Proquest to the faculty listings of the Directory of Graduate Research from the American Chemical Society. This data source has information on the age, gender as well as educational and professional histories of chemistry and chemical engineering faculty. ${ }^{5}$ Finally, we infer the area of specialization of faculty in our sample from the journals in which they publishes. For instance, a faculty member who often publishes in the Journal of Biological Chemistry is assumed to to be specialized in biochemistry. Table 2 displays a listing of areas of specialization and an example journal for each.

[insert table 2 about here]

\section{Descriptive statistics}

Our data cover virtually all U.S. PhD-granting departments in chemistry and chemical engineering. We have a total of 21,154 students graduating between 1999 and 2008 of whom 2,220 (10.49\%) are identified as Chinese by our name matching algorithm. The share of Chinese students is slightly increasing over time from an average of $9.5 \%$ for the graduation years from 1999 to 2003 to an average of $11.6 \%$ for the graduation years 2004 to 2008. The share of Chinese students exhibits considerable variation across universities. For instance, more than $50 \%$ of graduates from New York University are Chinese compared to less than $3 \%$ at the University of California, Berkeley. The fraction of Chinese students is markedly higher in schools with lower chemistry R\&D budgets. For instance, Chinese students represent $7.2 \%$ of students in the top 25 chemistry departments compared to $12.6 \%$ for the rest of the departments.

5,139 faculty advised at least one student graduating between 1999 and 2008, with a mean of 4 students and a maximum of 29. An interesting pattern that emerges in our data is that

\footnotetext{
${ }^{5}$ For more information about this database, see Gaule (2011)
} 
Chinese students are more likely to match with Chinese advisors. ${ }^{6} 29.0 \%$ of students advised by Chinese faculty in U.S. universities are themselves Chinese whereas the Chinese students represent only $10.5 \%$ of the student population. However, we only have 115 Chinese advisors in our sample (less than $3 \%$ of advisors) so that only $5.2 \%$ of Chinese students graduate with a Chinese advisor.

Finally, descriptive statistics by type of student for the six output measures are displayed in table 3. From this raw data, we can see that Chinese students have higher unconditional mean productivity than other students for the six output measures.

[insert table 3 about here]

\section{$5 \quad$ Estimation and results}

\subsection{Regressions at the individual student level}

In the first step of our analysis, we regress various measures of scientific output on an indicator variable for Chinese students. Our controls always include sets of indicator variables for the year of graduation and for the specialization of the adviaor. We alternate between specifications with school fixed effects, with advisors fixed effects and with neither of those.

Most regressions are estimated with a quasi-maximum likelihood conditional fixed-effects Poisson model ("Poisson QML"; see Hausman et al. 1984). This model has several desirable properties, including consistency of the coefficient estimates independently of any assumption on the conditional variance as long as the mean is correctly specified (Woolridge 1997) and consistency in the standard errors even if the data generating process is not Poisson. This estimator can also be used for fractional and non-negative variables (Santos Silva \& Tenreyro 2006), such as publications counts adjusted by journal impact factors in our case.

We implement this in Stata with the "xtqmlp" procedure written by Tim Simcoe. ${ }^{7}$ Poisson

\footnotetext{
${ }^{6}$ Similar patterns for a smaller sample are found by Tanyildiz (2008)

${ }^{7}$ Available for download at http://people.bu.edu/tsimcoe/code/xtpqml.txt
} 
QML estimates are interpreted as $(\exp (\beta)-1) * 100$ percentage change or approximately as $\beta * 100$ percentage change. ${ }^{8}$ They can thus be easily compared across regressions.

The results are displayed in table 4 . Each panel (A, B, C) presents the results obtained with different sets of fixed effects. The coefficient for Chinese student is positive and significant at $1 \%$ in all specifications. Comparing the coefficient for Chinese student horizontally across different productivity measures, the coefficient tends to be larger for citations than for raw publication counts, or counts weighted by journal impact factors. Since citations are usually thought to be a better proxy for the quality of research, this suggests that the productivity advantage of Chinese students is stronger in the quality dimension than in the quantity dimension. Comparing the Chinese student coefficient vertically across panels, we find that it is not sensitive to the inclusion of either school fixed effects or advisor fixed effects. Thus, the productivity differential of Chinese students does not seem to be explained by school or advisor characteristics. The point estimates range from 0.216 to 0.497 , implying that Chinese students are between $24.1 \%(100 *(\exp (0.216)-1))$ and $64 \%(100 * \exp ((0.497)-1)$ more productive than other students.

\section{[insert table 4 and 5 about here]}

So far, we have compared Chinese students to all other students combined. However, it is also interesting to compare Chinese students to other, more specific, populations of students. We thus repeat the same type of exercise and introduce indicator variables for Indian students, Korean students ${ }^{9}$, and Fellows of the National Science foundation (an elite group of American students). The results are displayed in panels D, E, and F of table 5. The results for the other groups of students are somewhat less stable across specifications than those for Chinese students, perhaps due to the smaller size of these groups. Nevertheless, clear patterns emerge. While Indian and Korean students outperform the residual group of students who are neither Chinese, Indian, Korean or NSF fellows, they systematically un-

\footnotetext{
${ }^{8}$ For instance, a coefficient of 0.216 corresponds to $\exp (0.216)-1=0.241 * 100=24.1 \%$ with $0.216 * 100=$ $21.6 \%$ a decent approximation.

${ }^{9}$ Indian and Korean students are identified using an ethnic name matching algorithm, like the Chinese students.
} 
derperform the Chinese students. Another interesting comparison is between the coefficient for Chinese students and the NSF fellows. Conditional on being in the same school (panel E) or having the same advisor (panel F), the Chinese students perform about as well the NSF fellows- America's best and brightest in Science and Engineering.

\subsection{Regressions at the individual advisor level}

We continue our analysis by using a completely different, but complementary, approach. We use the information we have on students and advisors to construct a panel of advisors over the years 2000-2007. We then regress the output of the advisor on the number of Chinese and other students graduating in that year, the preceding year, and subsequent year. The estimation is by ordinary least squares with robust standard errors. Our controls include school fixed effects, advisor age fixed effects and specialization fixed effects. As discussed earlier, a chemistry faculty member typically relies on her graduate students to conduct experiments that she conceives, and her name would invariably be included in the resulting publications.

[insert table 6 about here]

The results are shown in table 6. Having an extra Chinese student in the lab increases the output of the advisor by 0.895 paper per year on average whereas a non-Chinese student increases the output of the advisor by 0.630 only. A F-test rejects the equality between the coefficient for Chinese students coefficient and the coefficient for other students at the $1 \%$ confidence level. Similar results are obtained when using citations or publications weighted by journal impact factor. Thus, Chinese students seem to make a disproportionate contribution to the output of their advisors.

The results of these regressions should be interpreted with caution because graduate students are typically financed through grants to their advisors. Thus, the number of students that a faculty will have will reflect his (unobserved) past fund-raising success. Furthermore, the assignment of students to advisors may be non-random. While these considerations may 
threaten the consistency of point estimates for either type of students, it is less clear that they affect the difference between the two types of students. Thus, while the results at the advisor level are entirely consistent with those at the individual student level, we place more confidence in the individual student regressions.

\section{Discussion}

Why do the Chinese students perform well? Our preferred explanation is a selection effect. U.S. education enjoys an excellent reputation in China and attracts the brightest and most motivated Chinese students. Despite the fact that U.S. universities are admitting large numbers of Chinese students, it is nevertheless considerably more difficult for a Chinese than for a native to be accepted into a U.S. PhD program. Evidence from Attieh and Attieh (1997) suggests that top U.S. universities give substantial preference to U.S. citizens in their admission decisions. While this may reflect an underlying preference for natives, it could also be an optimal response to difficulties encountered in evaluating the applications of Chinese students (lack of familiarity with schools, grading systems and reference letter writers).

Precisely because of these difficulties, an undergraduate degree from one of the top Chinese universities is a de facto requirement for entry into a U.S. PhD program. Chinese graduate students come from a restricted set of elite Chinese universities such as Peking University and Tsinghua University. In China, around 10 million high school finishers take the national college entrance exam but only three thousand (0.03\%) are admitted into the two most prestigious schools, Peking University and Tsinghua University. Peking University and Tsinghua University are thus more selective than the most exclusive U.S. institutions; the majority of MIT undergraduates would not have had standardized test scores high enough to be admitted into the undergraduate programs of Peking University and Tsinghua University. ${ }^{10}$

Besides this positive selection story, two other plausible arguments could explain the

\footnotetext{
${ }^{10}$ The median SAT math score of MIT undergraduates is 770 which is lower than the top centile cutoff of the SAT score distribution.
} 
productivity advantage of the Chinese students. The first argument points to incentive effects due to higher preferences of the Chinese students for an academic career. The second explanation emphasizes a cultural predisposition of the Chinese students for higher effort at work.

According to the first argument, a career in academia and a post-doctoral training in particular may be relatively more attractive to Chinese students, thus increasing the incentives to publish during the $\mathrm{PhD}$. In particular, immigration considerations may be relevant as maintaining valid immigration status in the U.S. could be easier when undertaking postdoctoral training than when working in industry. ${ }^{11}$ However, data from the 2001 Survey of Earned Doctorates indicate that Chinese $\mathrm{PhD}$ students in chemistry are more likely than others to be planning to go to industry directly from graduate school (35.8\% of those born in China plan to work in industry, versus only $26.2 \%$ of those born anywhere else) and no more likely to be planning to follow postdoctoral training $(37.4 \%$ of the Chinese plan to follow postdoctoral training, versus 39.7\% of all other students) (Stephan 2010).

In support of the second argument, anecdotal evidence suggests that Chinese graduate students work harder and spend more time in the laboratory. Again, complementary evidence from other data sources suggests that this cultural predisposition for higher effort might be of second order importance. In fact, a survey of post-docs found only small differences between Chinese and Americans in terms of hours worked (50.5 hours per week versus 49.8; Brumfiel 2005).

\section{Concluding remarks}

The contribution of this paper is to show that Chinese students enrolled in U.S. PhD programs have a strong record of publications during their graduate studies and make disproportionate contributions to the productivity of their advisors and departments. We argue that this excellent performance of the Chinese with respect to other students is most likely

\footnotetext{
${ }^{11}$ From the perspective of immigration law, post-doctoral training is not considered as work. Most postdoctoral fellows are on visitor (J1) rather than on work (H1B) visas. The latter, but not the former, are subject to a yearly cap.
} 
explained by selection processes. Our findings strengthen and complement other studies that have found that migrant scientists and engineers make disproportionate contributions to U.S. innovation (Levin \& Stephan 1999; Hunt 2011, Stuen, Mobarak \& Maskus 2011; Chellaraj, Maskus \& Mattoo 2008, Gurmu, Black \& Stephan 2010). The influx of talented students is an important benefit to host universities. However, potential negative effects, and in particular the fact that migration may decrease incentives for natives to engage in scientific careers (Borjas 2006), should also be in taken into account.

Since the costs of training graduate students are mainly borne by the host country in the form of research and teaching assistantships, it is important to consider the stay rates of Chinese students. According to estimates derived by Finn (2007) using Social Security data, the stay rate for Chinese doctorate recipients is around $92 \%$ after five years from obtaining the title, the highest observed for any major source country in 2005. Similarly, Gaule (2011) finds that the lifetime odds of permanent return for Chinese migrants who become faculty in U.S. universities is less than $2 \%$. However, the current high stay rates cannot be taken for granted given the steadily rising skill premium in China and the aggressive recruiting policies of Chinese universities.

An important limitation of our study is that our research is based on an early measure of productivity - publication during the $\mathrm{PhD}$ - and does not address post-PhD outcomes. We do not know if Chinese students continue to outperform non-Chinese students after their training period. On the one hand, initial differences in scientific productivity tend to persist and might even amplify over time. On the other hand, post-graduate occupations may require skills that the Chinese immigrants may lack. Further evidence on productivity and mobility choices after the $\mathrm{PhD}$ would thus be useful to complete our understanding of the contribution of Chinese high-skilled migrants to U.S. innovation. 


\section{References}

Borjas G (2006) "Native Internal Migration and The Labor Market Impact Of Immigration" Journal of Human Resources 41(2)221-258.

Borjas G (2004) "Do Foreign Students Crowd Out Native Students from Graduate Programs? NBER Working Paper No. 10349. Cambridge, MA: National Bureau of Economic Research.

Bound J, Turner S \& Walsh P (2009) "Internationalization of U.S. doctorate education" NBER Working Paper No. 14792. Cambridge, MA: National Bureau of Economic Research.

Chellaraj G, Maskus K \& Mattoo A (2008) "The Contribution of International Graduate Students to U.S. Innovation" Review of International Economics 16(3):444-462.

Finn, M (2007) "Stay Rates of Foreign Doctorate Recipients from U.S. Universities, 2005”, Oak Ridge, TN: Oak Ridge Institute for Science and Education.

Freeman R (2009) "What Does Global Expansion of Higher Education Mean for the US?" NBER Working Paper No. 14962. Cambridge, MA: National Bureau of Economic Research.

Freeman R, Chang T \& Chiang H (2005) "Supporting the Best and Brightest in Science and Engineering: NSF Graduate Research Fellowships" NBER Working Paper No. 11623. Cambridge, MA: National Bureau of Economic Research.

Gaule P (2011) "Return migration: evidence from academic scientists" mimeo. MIT Sloan School of Management.

Gurmu S, Black C, Stephan P (2010) "The Knowledge Production Function for University Patenting" Economic Inquiry 48(1):192-213

Hausman J, Hall B \& Griliches Z (1986) "Econometric Models for Count Data with an Application to the Patents-R\&D Relationship Econometrica, 52:909-938.

Hunt J (2011) "Which Immigrants are Most Innovative and Entrepreneurial? Distinctions 
by Entry Visa" Journal of Labor Economics 29(3):411-457.

Hunt J \& Gauthier-Loiselle M (2010) "How Much Does Immigration Boost Innovation?" American Economic Journal: Macroeconomics 2(2): 3156.

Kahn S \& MacGarvie M (2011) "How Important is U.S. Location for Research in Science?" mimeo. Boston University.

Kahn S \& MacGarvie M (forthcoming) "The Effects of the Foreign Fulbright Program on Knowledge Creation in Science and Engineering" in Lerner J \& Stern S (eds) The Rate and Direction of Inventive Activity Revisited.

Kerr W (2008a) "Ethnic Scientific Communities and International Technology Diffusion" The Review of Economics and Statistics 90(3):518-537.

Kerr W (2008b) "The Ethnic Composition of US Inventors" HBS Working Paper 08-006. Boston, MA: Harvard Business School.

Kerr W \& Lincoln W (2010) "The Supply Side of Innovation: H-1B Visa Reforms and U.S. Ethnic Invention" Journal of Labor Economics 28(3):473-508

Levin S \& Stephan P (1999) "Are the Foreign Born a Source of Strength for U.S. Science?" Science 285(5431)1213-1214

MacGarvie M (2007) 'Using Published Dissertations to Identify Graduates' Countries of Origin." Unpublished manuscript prepared for presentation at the NBER Conference on Career Patterns of Foreign-born Scientists and Engineers, November 7, 2007.

McKenzie D \& Rapoport H (forthcoming) "Self-selection patterns in Mexico-U.S. migration: The role of migration networks" The Review of Economics and Statistics

Laudel G (2001) "Collaboration, creativity and rewards: why and how scientists collaborate" International Journal of Technology Management 22(7-8):762-781

Mervis J (2008) "US Graduate Training: Top Ph.D. Feeder Schools Are Now Chinese" Science 321(5886):185 
Mithas S \& Lucas H (2010) "Are Foreign IT Workers Cheaper? U.S. Visa Policies and Compensation of Information Technology Professionals" Management Science 56(5):745-765

NORC (2008) "Baccalaureate - Origins of U.S. Research Doctorate Recipients: 1997$2006 "$

NSF (2007a) "Asia's Rising Science and Technology Strength: Comparative Indicators for Asia, the European Union and the United States" National Science Foundation, Division of Science Resources Statistics. NSF-07-319. Arlington, VA

NSF (2007b) "Why did they come to the United States? A profile of immigrant scientists and engineers" National Science Foundation, Division of Science Resources Statistics. NSF07-324. Arlington, VA.

NSF (2009) "Science and Engineering Doctorate Awards: 2006" National Science Foundation, Division of Science Resources Statistics. Arlington, VA.

NSF (2011) "Science and Engineering Doctorate Awards: 2009" National Science Foundation, Division of Science Resources Statistics. Arlington, VA.

Passerman D (2011) "Do High-Skill Immigrants Raise Productivity? Evidence From Israeli Manufacturing Firms, 1990-1999" mimeo. Boston University.

Poston L \& Luo H (2007) "Chinese student and labor migration to the United States : Trends and policies since the 1980s" Asian and Pacific Migration Journal 16(3)323-355.

Santos Silva J \& Tenreyro S (2006) "The Log of Gravity" Review of Economics and Statistics 88:641-658.

Stephan P (2010) "Tabulations from Survey of Earned Doctorates" Discussion at NBER Summer Institute.

Stuen E, Mobarak A \& Maskus K (2011) "Foreign PhD Students and Knowledge. Creation at US Universities: Evidence from Enrollment Fluctuations" mimeo, University of Colorado. 
Tanyildiz Z (2008) "The effect of networks on U.S. institution selection by foreign doctoral students in Science \& Engineering" PhD Thesis, Georgia State University.

U.S. Department of State (various years) "Annual report of the visa office."

WestEd (2002) "National Science Foundation Graduate Research Fellowship Program: Final Evaluation Report".

Wooldridge J (1997) "Quasi-Likelihood Methods for Count Data" in Pesaran H \& Schmidt P (eds) Handbook of Applied Econometrics Oxford: Blackwell. 


\section{Tables}

Table 1: Using biographic information to verify the quality of the name matching

\begin{tabular}{cc}
\hline \hline & With Chinese name \\
Right Match & $88.2 \%$ are educated in China \\
Wrong Match & $11.8 \%$ not educated in China (5.1\% Taiwan) \\
& Educated in China \\
Right Match & $95.6 \%$ have a Chinese name \\
Wrong Match & $4.4 \%$ do not have a Chinese name \\
\hline \hline
\end{tabular}

Table 2: Using journals to define field of specialization

\begin{tabular}{ll}
\hline Field & Journal (example) \\
\hline Analytical chemistry & Analytical Chemistry \\
Applied Chemistry & Angewandte Chemie \\
Biochemistry & Journal of Biological Chemistry \\
Chemical Engineering & AIChE Journal \\
Inorganic Chemistry & Inorganic Chemistry \\
Material Science & Macromolecules \\
Organic Chemistry & Journal of Organic Chemistry \\
Nanotechnology & Nano Letters \\
\hline \hline
\end{tabular}

The area of specialization for a given faculty is inferred from the journals s/he publishes in. For instance, a faculty who publishes often in the Journal of Biological Chemistry is assumed to be specialized in biochemistry. 
Table 3: Descriptive statistics on scientific output

\begin{tabular}{lccccc}
\hline \hline & \multicolumn{2}{c}{$\begin{array}{c}\text { Chinese students } \\
(\mathrm{n}=2,220)\end{array}$} & & \multicolumn{2}{c}{$\begin{array}{c}\text { All other students } \\
(\mathrm{n}=18,934)\end{array}$} \\
\cline { 2 - 3 } \cline { 5 - 6 } & Mean & SD & & Mean & SD \\
First-authored publications & & & & & \\
Number & 1.16 & 1.47 & & 0.93 & 1.27 \\
JIF-weighted & 5.57 & 8.25 & & 4.63 & 7.38 \\
Cites to & 34.74 & 131.19 & & 27.19 & 83.48 \\
& & & & & \\
All publications & & & & & \\
Number & 1.81 & 2.48 & & 1.41 & 2.03 \\
JIF-weighted & 9.29 & 15.37 & & 7.25 & 12.24 \\
Cites to & 66.63 & 264.45 & & 46.01 & 139.88 \\
\hline \hline
\end{tabular}


Table 4: Regression results at the individual student level

\begin{tabular}{|c|c|c|c|c|c|c|}
\hline \multirow{4}{*}{$\begin{array}{l}\text { (A) } \\
\text { Chinese student }\end{array}$} & \multicolumn{3}{|c|}{ First-authored publications } & \multicolumn{3}{|c|}{ All publications } \\
\hline & Number & JIF-weighted & Cites to & Number & JIF-weighted & Cites to \\
\hline & $0.216^{* * *}$ & $0.189^{* * *}$ & $0.275^{* * *}$ & $0.247^{* * *}$ & $0.250^{* * *}$ & $0.396^{* * *}$ \\
\hline & $(0.021)$ & $(0.010)$ & $(0.004)$ & $(0.017)$ & $(0.007)$ & $(0.003)$ \\
\hline Year of graduation FE & Yes & Yes & Yes & Yes & Yes & Yes \\
\hline Lab specialization FE & Yes & Yes & Yes & Yes & Yes & Yes \\
\hline Students & 21,154 & 21,154 & 21,154 & 21,154 & 21,154 & 21,154 \\
\hline
\end{tabular}

(B)

First-authored publications

\begin{tabular}{|c|c|c|c|c|c|c|}
\hline Chinese student & $\begin{array}{c}\text { Number } \\
0.237^{* * *} \\
(0.033)\end{array}$ & $\begin{array}{c}\text { JIF-weighted } \\
0.248^{* * *} \\
(0.038)\end{array}$ & $\begin{array}{c}\text { Cites to } \\
0.370^{* * *} \\
(0.115)\end{array}$ & $\begin{array}{c}\text { Number } \\
0.265^{* * *} \\
(0.034)\end{array}$ & $\begin{array}{c}\text { JIF-weighted } \\
0.311^{* * *} \\
(0.042)\end{array}$ & $\begin{array}{c}\text { Cites to } \\
0.497^{* * *} \\
(0.122)\end{array}$ \\
\hline Year of graduation FE & Yes & Yes & Yes & Yes & Yes & Yes \\
\hline School FE & Yes & Yes & Yes & Yes & Yes & Yes \\
\hline Lab specialization FE & Yes & Yes & Yes & Yes & Yes & Yes \\
\hline Students & 21,133 & 21,133 & 21,133 & 21,133 & 21,133 & 21,133 \\
\hline Universities & 164 & 164 & 164 & 164 & 164 & 164 \\
\hline
\end{tabular}

(C)

First-authored publications

\begin{tabular}{|c|c|c|c|c|c|c|}
\hline Chinese student & $\begin{array}{c}\text { Number } \\
0.231^{* * *} \\
(0.027)\end{array}$ & $\begin{array}{c}\text { JIF-weighted } \\
0.239^{* * *} \\
(0.032)\end{array}$ & $\begin{array}{c}\text { Cites to } \\
0.297^{* * *} \\
(0.085)\end{array}$ & $\begin{array}{c}\text { Number } \\
0.236^{* * *} \\
(0.029)\end{array}$ & $\begin{array}{c}\text { JIF-weighted } \\
0.269^{* * *} \\
(0.034)\end{array}$ & $\begin{array}{c}\text { Cites to } \\
0.390^{* * *} \\
(0.090)\end{array}$ \\
\hline Year of graduation FE & Yes & Yes & Yes & Yes & Yes & Yes \\
\hline Advisor FE & Yes & Yes & Yes & Yes & Yes & Yes \\
\hline Students & 17,185 & 17,183 & 17,115 & 17,185 & 17,183 & 17,141 \\
\hline Advisors & 3,013 & 3,012 & 2,991 & 3,013 & 3,012 & 3,000 \\
\hline
\end{tabular}

Robust standard errors in parentheses. ${ }^{*} p<0.1$, ** $p<0.05, * * * p<0.01$

Note: Panel A specifications are estimated using a Poisson regression with robust standard errors. Panel B and C specifications are estimated by Poisson Quasi-Maximum Likelihood. The various productivity measures used as dependent variable are based on the papers published between three years before graduation and the year of graduation. 
Table 5: Regression results at the individual student level - continued

\begin{tabular}{|c|c|c|c|c|c|c|}
\hline \multirow[t]{2}{*}{ (D) } & \multicolumn{3}{|c|}{ First-authored publications } & \multicolumn{3}{|c|}{ All publications } \\
\hline & Number & JIF-weighted & Cites to & Number & JIF-weighted & Cites to \\
\hline Chinese student & $\begin{array}{c}0.234^{* * *} \\
(0.021)\end{array}$ & $\begin{array}{c}0.212^{* * *} \\
(0.010)\end{array}$ & $\begin{array}{c}0.300^{* * *} \\
(0.004)\end{array}$ & $\begin{array}{c}0.264^{* * *} \\
(0.017)\end{array}$ & $\begin{array}{c}0.270^{* * *} \\
(0.008)\end{array}$ & $\begin{array}{c}0.414^{* * *} \\
(0.003)\end{array}$ \\
\hline Indian student & $\begin{array}{c}0.104^{* * *} \\
(0.030)\end{array}$ & $\begin{array}{c}0.079^{* * *} \\
(0.014)\end{array}$ & $\begin{array}{c}0.027^{* * *} \\
(0.006)\end{array}$ & $\begin{array}{l}0.065^{* *} \\
(0.025)\end{array}$ & $\begin{array}{c}0.028^{* *} \\
(0.011)\end{array}$ & $\begin{array}{c}-0.065^{* * *} \\
(0.005)\end{array}$ \\
\hline Korean student & $\begin{array}{l}0.065^{*} \\
(0.035)\end{array}$ & $\begin{array}{c}0.108^{* * *} \\
(0.015)\end{array}$ & $\begin{array}{c}0.112^{* * *} \\
(0.006)\end{array}$ & $\begin{array}{l}0.049^{*} \\
(0.029)\end{array}$ & $\begin{array}{c}0.075^{* * *} \\
(0.012)\end{array}$ & $\begin{array}{c}0.074^{* * *} \\
(0.005)\end{array}$ \\
\hline NSF fellow & $\begin{array}{c}0.461^{* * *} \\
(0.045)\end{array}$ & $\begin{array}{c}0.654^{* * *} \\
(0.018)\end{array}$ & $\begin{array}{c}0.846^{* * *} \\
(0.007)\end{array}$ & $\begin{array}{c}0.499^{* * *} \\
(0.036)\end{array}$ & $\begin{array}{c}0.653^{* * *} \\
(0.014)\end{array}$ & $\begin{array}{c}0.803^{* * *} \\
(0.005)\end{array}$ \\
\hline $\begin{array}{l}\text { Year of graduation FE } \\
\text { Lab specialization FE }\end{array}$ & $\begin{array}{l}\text { Yes } \\
\text { Yes }\end{array}$ & $\begin{array}{l}\text { Yes } \\
\text { Yes }\end{array}$ & $\begin{array}{l}\text { Yes } \\
\text { Yes }\end{array}$ & $\begin{array}{l}\text { Yes } \\
\text { Yes }\end{array}$ & $\begin{array}{l}\text { Yes } \\
\text { Yes }\end{array}$ & $\begin{array}{l}\text { Yes } \\
\text { Yes }\end{array}$ \\
\hline$(\mathrm{E})$ & \multicolumn{3}{|c|}{ First-authored publications } & \multicolumn{3}{|c|}{ All publications } \\
\hline Chinese student & $\begin{array}{c}\text { Number } \\
0.256^{* * *} \\
(0.034)\end{array}$ & $\begin{array}{c}\text { JIF-weighted } \\
0.269^{* * *} \\
(0.039)\end{array}$ & $\begin{array}{c}\text { Cites to } \\
0.385^{* * *} \\
(0.108)\end{array}$ & $\begin{array}{c}\text { Number } \\
0.283^{* * *} \\
(0.035)\end{array}$ & $\begin{array}{c}\text { JIF-weighted } \\
0.328^{* * *} \\
(0.043)\end{array}$ & $\begin{array}{c}\text { Cites to } \\
0.502^{* * *} \\
(0.114)\end{array}$ \\
\hline Indian student & $\begin{array}{c}0.130^{* * *} \\
(0.042)\end{array}$ & $\begin{array}{c}0.137^{* * * *} \\
(0.045)\end{array}$ & $\begin{array}{c}0.104 \\
(0.066)\end{array}$ & $\begin{array}{c}0.094^{* *} \\
(0.043)\end{array}$ & $\begin{array}{l}0.090^{*} \\
(0.047)\end{array}$ & $\begin{array}{c}0.022 \\
(0.065)\end{array}$ \\
\hline Korean student & $\begin{array}{l}0.078^{*} \\
(0.047)\end{array}$ & $\begin{array}{l}0.111^{*} \\
(0.060)\end{array}$ & $\begin{array}{l}0.106 \\
(0.120)\end{array}$ & $\begin{array}{c}0.055 \\
(0.044)\end{array}$ & $\begin{array}{c}0.068 \\
(0.057)\end{array}$ & $\begin{array}{c}0.047 \\
(0.098)\end{array}$ \\
\hline NSF fellow & $\begin{array}{c}0.337^{* * *} \\
(0.043)\end{array}$ & $\begin{array}{c}0.301^{* * *} \\
(0.043)\end{array}$ & $\begin{array}{c}0.162 \\
(0.170)\end{array}$ & $\begin{array}{c}0.347^{* * *} \\
(0.047)\end{array}$ & $\begin{array}{c}0.256^{* * *} \\
(0.045)\end{array}$ & $\begin{array}{l}0.087 \\
(0.110)\end{array}$ \\
\hline Year of graduation FE & Yes & Yes & Yes & Yes & Yes & Yes \\
\hline School FE & Yes & Yes & Yes & Yes & Yes & Yes \\
\hline Lab specialization FE & Yes & Yes & Yes & Yes & Yes & Yes \\
\hline$(\mathbf{F})$ & \multicolumn{3}{|c|}{ First-authored publications } & \multicolumn{3}{|c|}{ All publications } \\
\hline Chinese student & $\begin{array}{c}\text { Number } \\
0.245^{* * *} \\
(0.027)\end{array}$ & $\begin{array}{c}\text { JIF-weighted } \\
0.256^{* * *} \\
(0.032)\end{array}$ & $\begin{array}{c}\text { Cites to } \\
0.316^{* * *} \\
(0.085)\end{array}$ & $\begin{array}{c}\text { Number } \\
0.246^{* * *} \\
(0.029)\end{array}$ & $\begin{array}{c}\text { JIF-weighted } \\
0.278^{* * *} \\
(0.034)\end{array}$ & $\begin{array}{c}\text { Cites to } \\
0.401^{* * *} \\
(0.092)\end{array}$ \\
\hline Indian student & $\begin{array}{c}0.145^{* * *} \\
(0.039)\end{array}$ & $\begin{array}{c}0.151^{* * *} \\
(0.046)\end{array}$ & $\begin{array}{c}0.160^{* *} \\
(0.072)\end{array}$ & $\begin{array}{c}0.094^{* *} \\
(0.039)\end{array}$ & $\begin{array}{c}0.076 \\
(0.046)\end{array}$ & $\begin{array}{c}0.054 \\
(0.063)\end{array}$ \\
\hline Korean student & $\begin{array}{c}0.040 \\
(0.043)\end{array}$ & $\begin{array}{c}0.055 \\
(0.059)\end{array}$ & $\begin{array}{l}0.088 \\
(0.124)\end{array}$ & $\begin{array}{l}-0.018 \\
(0.045)\end{array}$ & $\begin{array}{l}-0.030 \\
(0.060)\end{array}$ & $\begin{array}{l}-0.024 \\
(0.094)\end{array}$ \\
\hline NSF fellow & $\begin{array}{c}0.318^{* * *} \\
(0.053)\end{array}$ & $\begin{array}{c}0.335^{* * *} \\
(0.060)\end{array}$ & $\begin{array}{c}0.265^{* *} \\
(0.125)\end{array}$ & $\begin{array}{c}0.359^{* * *} \\
(0.055)\end{array}$ & $\begin{array}{c}0.323^{* * *} \\
(0.060)\end{array}$ & $\begin{array}{c}0.252^{* *} \\
(0.114)\end{array}$ \\
\hline Year of graduation FE & Yes & Yes & Yes & Yes & Yes & Yes \\
\hline Advisor FE & Yes & Yes & Yes & Yes & Yes & Yes \\
\hline
\end{tabular}

Robust standard errors in parentheses. ${ }^{*} p<0.1,{ }^{* *} p<0.05,{ }^{* * *} p<0.01$

Note: Panel E specifications are estimated using a Poisson regression with robust standard errors. Panel E and F specifications are estimated by Poisson Quasi-Maximum Likelihood. The various productivity measures used as dependent variable are based on the papers published between three years before graduation and the year of graduation. 
Table 6: Regressions at the individual advisor level

\begin{tabular}{lccc}
\hline \hline & \multicolumn{3}{c}{ Publications of the advisor } \\
\cline { 2 - 4 } & Number & JIF-Weighted & Cites to \\
\hline Number of Chinese students & $0.895^{* * *}$ & $4.641^{* * *}$ & $30.557^{* * *}$ \\
& $(0.086)$ & $(0.565)$ & $(7.497)$ \\
Number of other students & $0.630^{* * *}$ & $3.357^{* * *}$ & $18.604^{* * *}$ \\
& $(0.031)$ & $(0.214)$ & $(1.854)$ \\
\hline School fixed effects & Yes & Yes & Yes \\
Speciality fixed effects & Yes & Yes & Yes \\
Age fixed effects & Yes & Yes & Yes \\
\hline Observations & 34,005 & 34,005 & 34,005 \\
Advisors & 4,870 & 4,870 & 4,870 \\
\hline \hline
\end{tabular}

Robust standard errors in parentheses. ${ }^{*} p<0.1,{ }^{* *} p<0.05,{ }^{* * *} p<0.01$

We regress the output of the advisor on the number of Chinese and other students graduating in that year, the preceding year, and subsequent year. The panel is at the advisor-year level and runs from 2000 to 2007 . 
Table 7: Ethnic labs

\begin{tabular}{|c|c|c|}
\hline Chinese students & $\begin{array}{c}\text { as } \% \text { of all students } \\
10.5 \%\end{array}$ & $\begin{array}{l}\text { as \% of students with Chinese advisor } \\
\qquad 29.0 \%\end{array}$ \\
\hline Indian students & $\begin{array}{c}\text { as } \% \text { of all students } \\
5.8 \%\end{array}$ & $\begin{array}{l}\text { as } \% \text { of students with Indian advisor } \\
17.3 \%\end{array}$ \\
\hline Korean students & $\begin{array}{l}\text { as } \% \text { of all students } \\
4.1 \%\end{array}$ & $\begin{array}{l}\text { as } \% \text { of students with Korean advisor } \\
\qquad 32.3 \%\end{array}$ \\
\hline
\end{tabular}

Table 8: Ethnic labs - continued

\begin{tabular}{|c|c|c|}
\hline Students with Chinese advisor & $\begin{array}{c}\text { as } \% \text { of all students } \\
1.9 \%\end{array}$ & $\begin{array}{c}\text { as \% of Chinese students } \\
5.2 \%\end{array}$ \\
\hline Students with Indian advisor & $\begin{array}{c}\text { as } \% \text { of all students } \\
2.4 \%\end{array}$ & $\begin{array}{c}\text { as } \% \text { of Indian students } \\
7.2 \%\end{array}$ \\
\hline Students with Korean advisor & $\begin{array}{c}\text { as } \% \text { of all students } \\
0.5 \%\end{array}$ & $\begin{array}{c}\text { as } \% \text { of Korean students } \\
3.6 \%\end{array}$ \\
\hline
\end{tabular}




\section{Table 9: Interaction between Chinese student and Chinese advisor}

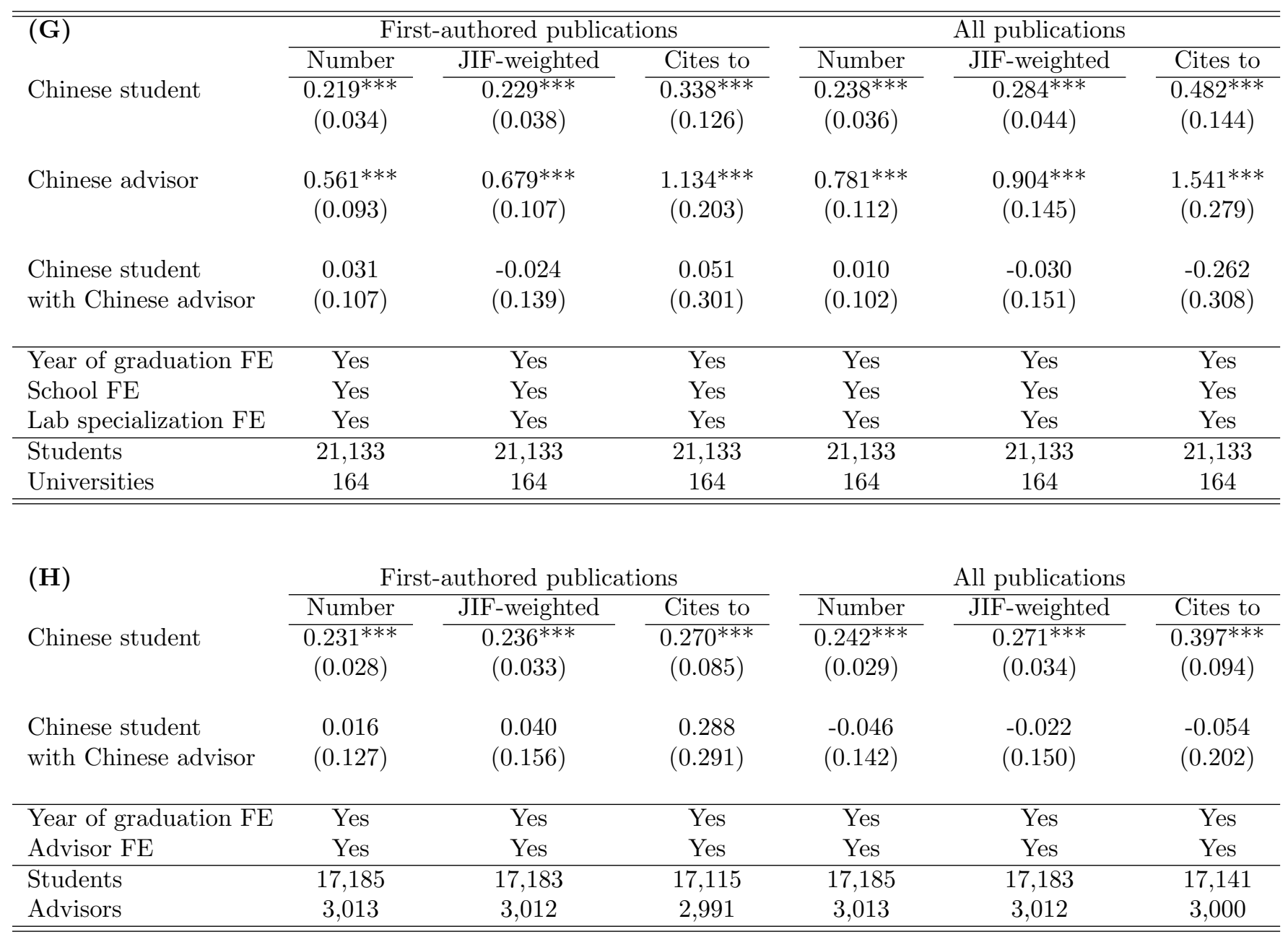

Robust standard errors in parentheses. ${ }^{*} p<0.1,{ }^{* *} p<0.05,{ }^{* * *} p<0.01$

Note: Panel $\mathrm{G}$ and $\mathrm{H}$ specifications are estimated by Poisson Quasi-Maximum Likelihood.

The various productivity measures used as dependent variable are based on the papers

published between three years before graduation and the year of graduation. 
Table 10: Baccalaureate-origin institutions of $\mathbf{P h D}$ graduates in $\mathbf{S} / \mathbf{E}$ from US Universities

\begin{tabular}{|c|c|c|c|c|c|c|}
\hline $\begin{array}{l}\text { Baccalaureate-origin } \\
\text { Institution }\end{array}$ & Country & Rank & $\begin{array}{l}\text { All S/E } \\
\text { doctorates }\end{array}$ & $\begin{array}{l}\text { Life } \\
\text { sciences }\end{array}$ & $\begin{array}{l}\text { Physical } \\
\text { Sciences }\end{array}$ & Eng. \\
\hline Tsinghua Univ & China & 1 & 542 & 17 & 104 & 421 \\
\hline Beijing Univ & China & 2 & 435 & 139 & 221 & 75 \\
\hline Seoul National Univ & Korea & 3 & 239 & 56 & 76 & 107 \\
\hline Cornell Univ & USA & 4 & 210 & 108 & 58 & 44 \\
\hline Univ of California-Berkeley & USA & 5 & 207 & 92 & 59 & 56 \\
\hline National Taiwan Univ & Taiwan & 6 & 176 & 64 & 49 & 63 \\
\hline Massachusetts Inst of Tech & USA & 7 & 171 & 44 & 64 & 63 \\
\hline Univ of Sci \& Tech China & China & 8 & 157 & 20 & 87 & 50 \\
\hline Univ of Illinois at Urbana-Champaign & USA & 9 & 153 & 70 & 27 & 56 \\
\hline Fudan Univ & China & 10 & 140 & 49 & 65 & 26 \\
\hline Nanking Univ & China & 11 & 138 & 42 & 68 & 28 \\
\hline Univ of Mumbai & India & 12 & 136 & 55 & 23 & 58 \\
\hline Pennsylvania State Univ-Main Campus & USA & 13 & 136 & 70 & 23 & 43 \\
\hline Univ of Michigan-Ann Arbor & USA & 14 & 134 & 52 & 34 & 48 \\
\hline Shanghai Jiaotong Univ & China & 15 & 133 & 8 & 27 & 98 \\
\hline Univ of Florida & USA & 16 & 132 & 71 & 23 & 38 \\
\hline Nankai Univ & China & 17 & 128 & 43 & 65 & 20 \\
\hline Univ of Wisconsin-Madison & USA & 18 & 125 & 74 & 27 & 24 \\
\hline The Univ of Texas at Austin & USA & 19 & 122 & 58 & 30 & 34 \\
\hline Univ of California-Davis & USA & 20 & 119 & 75 & 29 & 15 \\
\hline Harvard Univ & USA & 21 & 118 & 59 & 48 & 11 \\
\hline Brigham Young Univ & USA & 22 & 116 & 52 & 39 & 25 \\
\hline Univ of California-Los Angeles & USA & 23 & 116 & 61 & 38 & 17 \\
\hline Zhejiang Univ & China & 24 & 115 & 9 & 31 & 75 \\
\hline China Univ of Sci and Tech & China & 25 & 115 & 20 & 68 & 27 \\
\hline Total (incl. other institutions) & & & 20,057 & 7,909 & 6,151 & 5,997 \\
\hline
\end{tabular}

Source: Data from NORC(2008) based upon the NSF Survey of Earned Doctorates 
Table 11: Statistics of interest for the top 25 chemistry departments in our sample

\begin{tabular}{|c|c|c|c|c|c|c|}
\hline & School & $\begin{array}{l}\text { R \& D } \\
\text { exp. }\end{array}$ & $\begin{array}{l}\text { total \# } \\
\text { students }\end{array}$ & $\begin{array}{l}\# \text { NSF } \\
\text { fellows }\end{array}$ & $\begin{array}{l}\text { Chinese } \\
\text { (total) }\end{array}$ & $\begin{array}{l}\text { Chinese } \\
(\%)\end{array}$ \\
\hline 1 & California Institute of Technology & 36.9 & 186 & 26 & 16 & $8.6 \%$ \\
\hline 2 & Harvard University & 30.3 & 245 & 71 & 23 & $9.4 \%$ \\
\hline 3 & University of California-Berkeley & 29.5 & 449 & 37 & 17 & $3.8 \%$ \\
\hline 4 & University of Illinois-Urbana & 29.2 & 413 & 7 & 40 & $9.7 \%$ \\
\hline 5 & Texas A\&M University & 24.7 & 315 & 2 & 45 & $14.3 \%$ \\
\hline 6 & Georgia Institute of Technology & 24.4 & 183 & 1 & 24 & $13.1 \%$ \\
\hline 7 & University of California-San Diego & 23.6 & 206 & 3 & 11 & $5.3 \%$ \\
\hline 8 & University of California-Los Angeles & 23.3 & 285 & 3 & 28 & $9.8 \%$ \\
\hline 9 & University of Texas-Austin & 22.7 & 273 & 4 & 31 & $11.4 \%$ \\
\hline 10 & Rutgers & 22.0 & 131 & 0 & 50 & $38.2 \%$ \\
\hline 11 & Massachusetts Institute of Technology & 21.5 & 258 & 41 & 20 & $7.8 \%$ \\
\hline 12 & Northwestern University & 21.3 & 228 & 5 & 34 & $14.9 \%$ \\
\hline 13 & University of North Carolina-Chapel Hill & 21.0 & 311 & 6 & 18 & $5.8 \%$ \\
\hline 14 & Purdue University & 20.4 & 288 & 1 & 50 & $17.4 \%$ \\
\hline 15 & Pennsylvania State University & 19.6 & 229 & 3 & 24 & $10.5 \%$ \\
\hline 16 & Cornell University & 19.2 & 210 & 4 & 22 & $10.5 \%$ \\
\hline 17 & University of Washington-Seattle & 18.6 & 192 & 2 & 11 & $5.7 \%$ \\
\hline 18 & University of Colorado & 18.4 & 199 & 2 & 6 & $3.0 \%$ \\
\hline 19 & University of California-Irvine & 17.9 & 216 & 0 & 15 & $6.9 \%$ \\
\hline 20 & University of Wisconsin-Madison & 17.9 & 445 & 15 & 30 & $6.7 \%$ \\
\hline 21 & Stanford University & 17.8 & 232 & 31 & 28 & $12.1 \%$ \\
\hline 22 & Johns Hopkins University & 17.1 & 99 & 0 & 10 & $10.1 \%$ \\
\hline 23 & University of Michigan & 16.6 & 264 & 2 & 34 & $12.9 \%$ \\
\hline 24 & Louisiana State University & 16.5 & 95 & 0 & 9 & $9.5 \%$ \\
\hline 25 & Emory University & 16.4 & 123 & 0 & 36 & $29.3 \%$ \\
\hline
\end{tabular}

Notes: R \& D expenditures refers to 2007 R\&D expenditures in chemistry in million USD. The number of students, Chinese students and NSF fellows are based on students graduating from chemistry departments between 1999 and 2008 